Jurnal Ilmu Sosial dan Pendidikan (JISIP)

Vol. 5 No. 3 Juli 2021

Terakreditasi Peringkat 5 (No. SK: 85/M/KPT/2020)

e-ISSN : 2656-6753, p-ISSN: 2598-9944

DOI: 10.36312/jisip.v5i3.2188 /http://ejournal.mandalanursa.org/index.php/JISIP/index

\title{
Analisis Proses Pembelajaran Bahasa Indonesia Menggunakan Pendekatan Saintifik
}

\author{
Muslihun ${ }^{1}$, Abdul Wachid B.S ${ }^{2}$ \\ ${ }^{1,3}$ UIN Prof. Saifuddin Zuhri Purwokerto \\ ${ }^{2}$ UIN Prof. Saifuddin Zuhri Purwokerto
}

\section{Article Info \\ Article history: \\ Article Receved: July 092021 \\ Publication: July 112021}

Keywords:
Prosentase
pembelajaran
Hasil Belajar

Article Info

Article history:

Artikel diterima: Juli 092021

Publikasi : Juli 112021

\begin{abstract}
Penelitian ini bertujuan : 1) untuk mengetahui penerapan pendekatan saintifik pada proses pembelajaran Bahasa Indonesia, dan 2) untuk mengetahui ada tidaknya perbedaan hasil evaluasi belajar"mata pelajaran Bahasa Indonesia"bagi siswa yang menggunakan penerapan pendekatan saintifik tinggi dengan siswa yang menggunakan penerapan pendekatan saintifik rendah. Ditinjau dari tujuannya, metode penelitiannya adalah penelitian deskriptif dan penelitian inferensial. Sedangkan objek penelitiannya mengacu pada proses pembelajaran Bahasa Indonesia. Sampling dari penelitian ini diambil dengan teknik Accidental dimana proses belajar bahasa Indonesia siswa kelas 5 MIM Langgar yang dilakukan selama 6 hari pada saat penelitian ini dilakukan. Kegiatan penelitian di akhiri dengan evaluasi menggunakan tes, kuesioner,angket dan pedoman observasi. Dari hasil evaluasi tersebut kemudian di adakan analisa dengan menggunakan analisis statistik deskriptif dan analisis statistik inferensial (uji-t). Penelitian ini menemukan hasil : (1) adanya penerapan pendekatan saintifik pada proses pembelajaran Bahasa Indonesia siswa kelompok VA tergolong sedang, sedangkan penerapan Pendekatan saintifik siswa kelompok 5B tergolong tinggi, (2) ditemukan hasil belajar yang berbeda peserta didik pada kelompok 5A dan kelompok 5B. Siswa kelompok 5A mengikuti pembelajaran dengan prosentase saintifiknya lebih tinggi, unggul pada prestasi belajarnya dari pada siswa kelompok 5B dengan mengikuti pembelajaran dengan prosentase saintifik yang rendah.

Abstract
This study aims: 1) to determine the application of the scientific approach to the
Indonesian language learning process, and 2) to determine whether there are
differences in the results of the evaluation of learning "Indonesian subjects" for
students who use the application of a high scientific approach to students who use
the application of a low scientific approach. Judging from the objectives, the
research method is descriptive research and inferential research. While the object
of research refers to the process of learning Indonesian. Sampling from this study
was taken using the Accidental technique where the Indonesian language learning
process for 5th grade MIM Langar students was carried out for 6 days at the time
this research was conducted. The research activity ended with an evaluation using
tests, questionnaires, questionnaires and observation guidelines. From the results of
the evaluation, then an analysis was carried out using descriptive statistical
analysis and inferential statistical analysis (t-test). This study found the results: (1)
the application of a scientific approach to the Indonesian language learning
process of students in the VA group was classified as moderate, while the
application of the scientific approach to students in the 5B group was classified as
high, (2) the different learning outcomes of students in the 5A and 5B groups were
found. Group 5A students take lessons with a higher scientific percentage, excel in
learning achievement than students in group 5B by taking lessons with a low
scientific percentage.
\end{abstract}

This is an open access article under the Lisensi Creative Commons AtribusiBerbagiSerupa 4.0 Internasional 


\section{Corresponding Author:}

Universitas Islam Negeri Prof. KH. Saifuddin Zuhri (UIN SAIZU) Purwokerto

Email: muslihun762@gmail.com

\section{PENDAhULUAN}

Proses pembelajaran yaitu ada suatu proses yang harus dilewati oleh peserta didik untuk meningkatkan kemampuan dirinya. Pada hakekatnya proses pembelajaran bisa diinterpretasikan sebagai usaha penuh dengan kesadaran dan perncanaan yang matang untuk bisa mewujudkan pada situasi pembelajaran atau proses belajar yang aktif guna menggali kemampuan diri untuk memiliki ketrampilan spiritual, mampu mengendalikan diri, memiliki kepribadian, kecerdasan berpikir, berakhlak mulia, serta keterampilan lain yang diperlukan dirinya dikemudian hari ketika hidup dilingkungan masyarakat. (UU. No. 20; 2003).

Bagi suatu bangsa keberadaan pendidikan mempunyai peran yang sangat urgen didalam upaya pengembangan potensi yang ada pada bangsa itu sendiri, sehingga bangsa itu memiliki sumber daya manusia berkualitas dan mampu bersaing pada era kemajuan zaman juga termasuk bagi bangsa Indonesia. PISA (Programme for International Student Assessment); 2012, dalam surveynya mengemukakan bahwa mutu pendidikan di Indonesia masih dibawah negara-negara lain, seperti yang tersaji pada tabel 1 , berikut :

2. Tabel : 1

Rata-rata Skor negara pada bidang Matematika, Membaca dan Sains

\begin{tabular}{|l|l|l|c|}
\hline No & \multicolumn{1}{|c|}{ Bidang } & \multicolumn{1}{c|}{ Negara } & Skor Rata-rata \\
\hline 1 & Matematika & Shanghai Cina & 613 \\
\hline & & Singapura & 573 \\
\hline & & Thailand & 427 \\
\hline & & Malaysia & 421 \\
\hline 2 & Membaca & Indonesia & 375 \\
\hline & & Shanghai Cina & 570 \\
\hline & & Singapura & 542 \\
\hline & & Thailand & 441 \\
\hline 3 & Sains & Malaysia & 398 \\
\hline & & Indonesia & 396 \\
\hline & & Shanghai Cina & 580 \\
\hline & & Singapura & 551 \\
\hline & & Thailand & 444 \\
\hline
\end{tabular}

Dari data survey tersebut Indonesia berada pada posisi terendah dari Negara-negara lain.

Rendahnya mutu pendidikan yang ada di Indonesia karena beberapa faktor penyebab diantaranya, kurangnya kemahiran pendidik dalam mengelola proses pembelajaran dan lemahnya potensi guru dalam penerapan pendekatan atau metode dalam pebelajaran, sehingga berpengaruh pada minat siswa dalam belajar dan pemahaman siswa dalam mencerna materi. Oleh karenanya, lembaga pendidikan yang ada di Indonesia dituntut agar selalu meningkatkan mutu dan kualitas pendidikan sebagai upaya peningkatan hasil pendidikan agar menjadi lebih baik.

Usaha peningkatan kualitas pendidikan di Indonesia ditandai adanya penyempurnaanpenyempurnaan kurikulum yang merupakan pedoman atau acuan bagi guru di dalam pelaksanaan proses pembelajaran. Hal penting dari proses pembelajaran, khususnya pada pendidikan resmi, 
adanya kegiatan proses belajar mengajar di sekolah yang disusun dan direncanakan demikian rupa dalam bentuk kurikulum, dengan harapan proses pembelajaran dapat berjalan semestinya dan mampu menciptakan lulusan (output) yang memiliki nilai jual. Skenario pembelajaran tersebut memiliki posisi yang penting karena terlaksananya serangkaian kegiatan proses belajar mengajar yang harus dilakukan ada di dalamnya.

Rancangan pembelajaran yang dipakai sebagai acuan dan panduan dalam kegiatan belajar mengajar yang diimplementasikan pada kurikulum, yaitu perangkat rencana dan aturan yang meliputi tujuan, isi, bahan pelajaran serta cara atau metode yang digunakan sebagai pedoman penyelenggaraan kegiatan belajar mengajar agar tercapai tujuan pendidikan". Oleh karenanya, perangkat kurikulum memiliki peran sentral pada proses pembelajaran. (UU.No.20 Tahun 2013).

Kurikulum hanyalah berupa acuan atau pedoman di dalam proses pembelajaran, adanya perbaikan kurikulum diharapkan akan membawa dampak peningkatan mutu atau kualitas pendidikan, kurikulum tersebut harus dimplementasikan dalam proses pembelajaran. Kurikulum adalah sebuah system yang tertuang tulisan digunakan untuk membantu tercapainya tujuan belajar mengajar yang disusun demikian rupa supaya berjalannya proses pembelajaran bagi peserta didik yang bersifat internal. (Zainal Arifin, 2012: 10). Dalam pelaksanaan pembelajaran pendidik memegang peran penting agar dapat terwujudnya perlaksanaan rancangan dari kurikulum tersebut.

Menurut kurikulum 2013 pembelajaran terselenggara untuk pengembangan kemampuan dan sikap serta memberikan pengetahuan dan keterampilan bagi peserta didik mengenai dasar yang diperlukan dalam kehidupan bermasyarakat kelak. Agar tercapai maksud tersebut diperlukan adanya proses pendidikan dan pengajaran dari berbagai bidang ilmu, yang salah satu diantaranya adalah pembelajaran Bahasa Indonesia. Pada kegiatan belajar bahasa Indonesia ini merupakan kegiatan pembelajaran yang mempunyai tujuan supaya peserta didik memiliki ketrampilan menggunakan bahasa Indonesia dengan benar dan baik, serta dapat mempelajari bahasa dan sastra Indonesia sesuai dengan kaidah berbahasa pada peserta didik. Dalam pembelajaran bahasa Indonesia, terdapat empat aspek keterampilan berbahasa yang harus dipelajari oleh siswa, yaitu: a) ketrampilan mendengarkan; b) ketrampilan berbicara; c) ketrampilan membaca; d) ketrampilan menulis. Aspek ketrampilan berbahasa tersebut saling terkait satu sama yang lain. (Daryanto, Kurinasih dan Sani, 2014).

Pada kenyataannya dilapangan menunjukkan, hasil belajar bahasa Indonesia pada siswa yang masih rendah, dibuktikan hasil Ujian Nasional dan hasil ulangan umum yang masih tergolong rendah, kurangnya kemampuan berbahasa Indonesia dan mengkomunikasikannya dengan benar dan baik di kalangan siswa SD sampai siswa sekolah lanjutan juga membuktikan masih rendahnya kualitas pendidikan di Indonesia.

Guna peningkatan proses dan evaluasi belajar peserta didik, pemerintah Indonesia yang membidangi yakni Kemendikbud pada tahun 2013-2014, mengadakan perbaikan panduan atau acuan yaitu pada Kurikulum 2013. Kurikulum tersebut mengamanatkan diselenggarakannya proses belajar mengajar yang menggunakan beragam pendekatan yang salah satunya adalah pendekatan saintifik, yaitu suatu pendekatan dimana proses belajar mengajar yang terdiri 5 pokok pengalaman belajar sesuai pendapat (Kurinasih dan Sani; 2014), yang meliputi: a) Mengamati, b) Menanya, c) Mengumpulkan data/Eksperimen, d) Mengasosiasi/Mengolah Informasi, e) Mengkomunikasikan.

Melalui pendekatan saintifik siswa dituntut supaya belajar mengamati dengan menggunakan panca indranya untuk dapat menggali berbagai informasi, kemudian masalah tersebut dirumuskan yang bersumber dari pengalaman belajar yang di peroleh, memberikan tanggapan teoritik atas permasalahan yang telah dirumuskan, dan melakukan eksperimen untuk menguji jawaban teoritik tersebut. Dalam pendekatan saintifik siswa juga dituntut belajar agar mampu menelaah informasi dengan pemahaman yang logis, kemudian dari informasi yang diperoleh melalui pengamatan atau uji coba tersebut untuk digali guna mengetahui ada tidaknya 
keterkaitan informasi yang satu dengan informasi lain. Melalui pendekatan ini juga diharapkan agar siswa mampu membangun berbagai jaringan dan mampu berkomunikasi untuk menggali berbagai pengetahuan, pengalaman dan ketrampilan yang ada pada diri siswa itu sendiri.

Diterapkannya pendekatan saintifik dalam pembelajaran, tidak terkecuali dalam mata pembelajaran bahasa Indonesia di SD, diharapkan agar para pendidik mampu meningkatan kualitas belajar mengajarnya, yang menurut Sudjana (Marjan; 2014) diartikan sebagai kemampuan yang dimiliki peserta didik setelah menerima materi dan dilakukan evaluasi guna mengetahui hasil akhir dari pembelajaran itu sudah tercapai dan sesuai tujuan pembelajarannya.

Memperhatikan temuan dan teori yang ada dapat ditarik kesimpulan bahwa secara konsep pentingnya diterapkannya pendekatan saintifik adalah agar meningkatnya kualitas belajar mengajar, sebab didalam proses belajar mengajar yang menggunakan pendekatan saintifik, diharapkan siswa mampu membentuk kemampuan mengkonsep, mengetahui tentang hukum atau prinsip melalui tahap perumusan masalah, mampu mengamati situasi dan selanjutnya mengajukan hipotesa, mampu mengumpulkan data dengan baik, mampu membuat analisa, mampu menyimpulkan dan mengkomunikasikan, sehingga pada akhirnya kualitas belajar dapat ditingkatkan.

Namun dari kesimpulan itu hanya bersifat teoritik atau konseptual saja, untuk membuktikannya itu diperlukan bukti-bukti yang empirik. Bukti-bukti empirik tersebut dapat diperoleh dari berbagai pendekatan yang salah satunya adalah pentingnya diterapkan pendekatan saintifik dalam pemebelajaran yang sampai saat ini belum banyak ditemukan. Untuk menemukan kadar saintifik pembelajaran dan dampaknya terhadap hasil belajar, khususnya dalam pelajaran bahasa Indonesia di SD, maka penelitian ini dilakukan dengan tema : Analisis Proses Pembelajaran Bahasa Indonesia Menurut Pendekatan Saintifik dan Dampaknya Terhadap Hasil Belajar Siswa Kelas 5 (lima) di MIM Langgar Kecamatan Kejobong Kabupaten Purbalingga.

\section{METODE PENELITIAN}

Berdasar dari tujuan yang hendak dicapai merupakan rancangan kajian yang peneliti gunakan dengan rancangan penelitian,deskriptif dan inferensial. Rancangan penelitian deskriptif,digunakan untuk menjelaskan, merinci atau membuat deskripsi terhadap proses pembelajaran menurut pendekatan saintifik. Selanjutnya,dari rancangan penelitian inferensial,tersebut digunakan,untuk mengambil sebuah keputusan,atau menguji hipotesa. Pengujian hipotesa ini dilakukan,untuk mengetahui,seberapa besar dampak dari,penerapan pendekatan saintifik pada proses pembelajaran,terhadap materi bahasa Indonesia di kelas 5 MIM Langgar. Pada penelitian ini digunakan rancangan penelitian deskriptif,untuk menjawab masalah yang pertama dan untuk menjawab masalah kedua,pada penelitian ini peneliti gunakan rancangan inferensial.

Rancangan deskriptif , Menurut Hidayat (2010); adalah,rancangan penelitian yang dimanfaatkan untuk mengetahui suatu ilmu yang seluas-luasnya terhadap objek penelitian pada satu masa tertentu. Sedangkan menurut Setyosari (2010); menjelaskan bahwa,penelitian deskriptif,adalah penelitian yang bertujuan,untuk menjelaskan,atau mendeskripsikan,suatu keadaan, peristiwa, objek apakah itu orang, atau segala sesuatu yang terkait dengan variabel yang bisa dijelaskan,dengan data maupun angka. Sukmadinata,(dalam Fatimah, 2013); mengemukakan, rancangan penelitian deskriptif yaitu suatu penelitian yang terbentuk guna mengungkap suatu peristiwa, baik yang alami, atau yang buatan. Peristiwa tersebut,dapat tercermin dalam wujud, sikap, watak, hubungan, kesamaan dan perbedaan antara satu dengan yang lain.

Sedangkan rancangan inferensial, menurut Gading (2014); yaitu,penelitian yang dilakukan dengan penerapan tahapan uji analisis dan uji hipotesis hubungan antar variable, dimana mencari simpulan,berdasar pada olahan data,dengan menggunakan metode statistik, Dari data yang diteliti tersebut kemudian dikumpulkan,dengan menggunakan,pedoman observasi, tes dan kuesioner, 
selanjutnya dari data itu,lalu dianalisa memakai statistik 'deskriptif 'dan statistik 'inferensial',(ujit).

Analisis statistik"deskriptif" dipakai guna menentukan ukuran kesaintifikan proses belajar bahasa Indonesia dengan menggunakan kreteria kurve normal dengan"rata-rata ideal"(Mi) dan"standar deviasi ideal"(SDi) yang dijadikan ukuran, sedangkan analisis statistik infrensial,dengan teknik uji-t (Gruilford, Frunchter, 1973) digunakan untuk menguji hipotesis. Langkah dilakukannya uji hipotesis, terlebih dulu perlu di uji analisisnya yang meliputi,: 1), uji normalitas sebaran data dan 2).uji homogenitas varian (Koyan, 2012).

\section{HASIL PENELITIAN DAN PEMBAHASAN}

Untuk uji normalitas sebaran data dibuat dua kelompok yakni koefisien untuk kelompok VA dan koefisien untuk kelompok VB, yang nantinya akan dapat disimpulkan bahwa dari data hasil belajar kelompok VA dan dari kelompok VB yang menjadi subjek penelitian ini.

Analisis deskriptif pada penelitian ini dimaksudkan untuk menemukan kadar kesaintifikan proses pembelajaran bahasa Indonesia. Mengacu pada kriteria penentuan kadar kesaintifikan proses pembelajaran bahasa Indonesia sebagaimana ditampilkan pada tabel 2, sedangkan hasil analisis deskriptif tentang ukuran kesaintifikan proses pada penelitian ini seperti ditampilkan pada tabel 3.

Tabel : 2. Kriteria Rentang Skor dan Kategori Ukuran Kesaintifikan Proses.

\begin{tabular}{|c|ccc|}
\hline & Kriteria Kurve Normal & Rentang Skor & Katagori \\
\hline & $>\mathrm{Mi}+1 \mathrm{SDi}$ & $>20$ & Tinggi \\
\hline & $\mathrm{Mi}-1 \mathrm{SDi}=\mathrm{Mi}+1 \mathrm{SDi}$ & $10-20$ & Sedang \\
\hline & $<\mathrm{Mi}-1 \mathrm{SDi}$ & $<10$ & Rendah \\
\hline
\end{tabular}

Tabel : 3. Analisa Deskriptif Ukuran Kesaintifikan Proses

\begin{tabular}{|l|ccc|}
\hline No. & Kelompok & Rata-rata (Mean) & Kategori \\
\hline 1. & VA & 12 & Sedang \\
\hline 2. & VB & 24 & Tinggi \\
\hline
\end{tabular}

Analisis infrensial pada penelitian ini dilakukan guna mengetahui hipotesa yang ada, dilihat dari hasil belajar bahasa Indonesia siswa menurut ukuran kesaintifikan pembelajaran.

Berdasarkan deskripsi data hasil penelitian diatas, ditemukan bahwa penerapan pendekatan saintifik pada proses belajar mengajar bahasa Indonesia di kelompok 5B termasuk kategori tinggi, sedangkan penerapan pendekatan saintifik di kelompok 5A termasuk kategori sedang. Hal itu didasarkan pada rata-rata skor yang diperoleh dari hasil pedoman observasi selama 6 hari. Kelompok 5B adalah 24 ada pada posisi kategori tinggi, sedangkan ratarata skor yang diperoleh kelompok 5A adalah 12 ada pada posisi kategori sedang.

Selanjutnya berdasar deskripsi data dari hasil penelitian tersebut, siswa yang tergabung dalam kelompok dengan penerapan pembelajaran menggunakan pendekatan saintifik tinggi memiliki hasil belajar yang lebih tinggi dibandingkan dengan siswa yang mengikuti penerapan pembelajaran dengan pendekatan lain memiliki hasil belajar sedang. Tinjauan ini berdasar pada rata-rata perolehan skor hasil belajar siswa. Perolehan skor dari evaluasi siswa dengan mengikuti pembelajaran menggunakan pendekatan saintifik tinggi adalah sebanyak 24 dan perolehan skor hasil evaluasi siswa yang mengikuti pembelajaran dengan penerapan pendekatan saintifik rendah sebanyak 12 .

Perbedaan yang mencolok tersebut disebabkan adanya perbedaan pada strategi penerapan pendekatan saintifik proses pembelajarannya. Pembelajaran menggunakan pendekatan saintifik merupakan proses pembelajaran yang mengandung pendekatan ilmiah yaitu adanya proses : 
mengamati, menanya, mengumpulkan informasi, mengasosiasi dan mengkomunikasikan; (Abidin, 2014).

Pada tahap mengamati (observasi), siswa pada kelompok 5B dengan sungguh-sungguh memperhatikan dan mengamati yang sedang disampaikan oleh gurunya, terlihat siswa ada yang bermain-main saat proses belajar berjalan, sehingga siswa kelompok 5B dengan mudah memahami pelajaran yang diajarkan oleh gurunya. Selanjutnya siswa pada kelompok VA dalam aspek mengamati terlihat masih banyak siswa yang tidak fokus dalam mendengarkan saat pelajaran diajarkan oleh guru, banyak siswa terlihat bermain sendiri dan mengganggu teman yang lain pada saat pembelajaran berlangsung, sehingga berpengaruh pada pemahaman siswa atas apa yang diinformasikan oleh guru. Hal tersebut senada dengan dinyatakan oleh Daryanto; (2014) bahwa pembelajaran dengan pendekatan saintifik mementingkan hikmah dari proses belajar mengajar (meaning full learning).

Dalam Tahap mengamati ini memiliki keunggulan tertentu, seperti rasa ingin tahu, ingin mencoba, ingin membuktikan dan lain sebagainya. Dari rasa keinginan siswa tersebut maka proses pembelajaran memiliki kebermaknaan yang tinggi. Dengan pengamatan yang baik, maka siswa akan mampu mengikuti proses pembelajaran dan menerima apa yang disampaikan oleh guru.

Pada tahap menanya, siswa pada kelompok 5B juga terlihat aktif dalam bertanya apabila menemukan hal yang masih kurang dimengerti oleh siswa dan kemudian ditanyakan kepada guru yang mengajar guna memperoleh informasi dari yang diamati. Kreteria pertanyaan yang diajukan juga tergolong singkat dan jelas, menginspirasi jawaban, memiliki fokus, bersifat probing dan validatif. Sedangkan pada siswa kelompok 5A, pada aspek menanya juga terlihat hanya beberapa siswa yang aktif dalam bertanya. Hal ini dikarenakan oleh adanya ketidak seriusan siswa dalam mengikuti pembelajaran yang berakibat menjadi gagal paham pada apa yang disajikan guru dan menjadikan kebingungan siswa dalam mengajukan pertanyaan. Ada beberapa siswa yang mengajukan pertanyaan juga masih kurang logis dan menyimpang dari materi yang diajarkan.

Temuan ini sesuai dengan pandangan Kurinasih; (2014) yang mengatakan bahwa, pada tahap menanya, pendidik yang baik bisa mengilhami siswa agar dapat mengembangkan kemampuan yang terdapat pada dirinya. Di saat guru menyampaikan pertanyaan, maka guru secara tidak langsung membimbing siswa agar belajar memahami, dan pada saat guru memberikan jawaban atas pertanyaan siswa, ketika itu secara tidak langsung guru memotivasi siswanya itu untuk mendengarkan dan memperhatikan dengan seksama terhadap apa yang dijelaskan oleh guru.

Pada tahap mengumpulkan informasi siswa kelompok 5B mampu melakukan eksperimen atas apa yang telah dipelajari. Tingkat pemahaman siswa ini dikarenakan siswa pada kelompok 5B sungguh-sungguh dalam mengamati dan aktif dalam bertanya tentang apa yang belum dipahaminya. Sedangkan pada siswa kelompok 5A, terlihat belum mampu mengumpulkan informasi dengan baik. Hal tersebut adalah sebagai bukti adanya ketidakmampuan sebagian besar siswa tidak mampu mengerjakan tugas yang diberikan. Temuan ini sejalan dengan pendapat Abidin; (2014) yang menyatakan bahwa, tahap mengumpulkan informasi merupakan tindak lanjut dari bertanya. Kegiatan ini dilakukan dengan menggali dan mengumpulkan informasi dari berbagai sumber melalui berbagai cara. Untuk itu siswa dapat melakukan kegiatan dengan banyak membaca buku, memperhatikan fenomena atau objek yang lebih teliti, atau bahkan melakukan eksperimen.

Pada tahap menalar atau mengasosiasi siswa pada kelompok 5B sudah terlihat sangat baik. Hal ini dibuktikan dengan siswa terlihat mampu mengaitkan antara informasi yang didapatkan sebelumnya dengan informasi yang didapatkan saat ini. Selanjutnya pada kelompok kelompok 5A tahap mengasosiasi masih kurang. Hal ini dibuktikan dengan tidak mampunya siswa dalam menghubungkan informasi dengan informasi yang didapatkan sebelumnya. Hal ini sejalan dengan pendapat Daryanto; (2014) yang berpendapat; tahap mengasosiasikan atau menalar merupakan kegiatan yang untuk mencari informasi ada tidaknya keterkaitan informasi satu dengan yang lain. Pada kegiatan ini disebut sebagai kegiatan menalar, yakni kegiatan yang 
memerlukan proses berpikir yang logis dan sistematis atas fakta yang dapat di observasi untuk dapat disimpulan menjadi sebuah pengetahuan. Kegiatan menalar pada pembelajaran didalam kurikulum (K'13) dengan penerapan pendekatan yang ilmiah mengacu pada teori belajar asosiatif. Dalam pembelajaran asosiasi yakni membidik kemampuan siswa agar mampu mengelompokkan beragam ide dan mengasosiasikan bermacam-macam kejadian untuk disimpan dalam ingatan. Dari pengalaman kejadian yang sudah tersimpan pada ingatan akan berkorelasi dengan pengalaman sebelumnya.

Selanjutnya pada tahap mengkomunikasikan, siswa pada kelompok kelompok 5B terlihat mampu menyampaikan informasi yang telah dipelajari dengan bukti ketika perintah oleh guru untuk menyampaikan hasil belajarnya dengan maju kedepan kelas, mereka mampu menyampaikan hasil belajarnya dengan jelas dan mudah untuk dimengerti. Berbeda dengan siswa kelompok 5A yang masih terlihat kurang mampu menyampaikan informasi yang didapatkan di depan kelas dengan baik. Masih banyak siswa yang terlihat malu-malu dalam menyampaikan hasil belajarnya dan kesimpulan materi yang disampaikan terlihat masih kurang jelas dan sedikit menyimpang dari materi yang telah diajarkan. Temuan ini didukung oleh pendapat Abidin; (2014) bahwa pada tahap memberitahukan (mengkomunikasikan), pendidik diharap memberikan kesempatan terhadap peserta didik untuk dapat menyampaikan tentang apa yang telah mereka pelajari. Langkah ini dapat dilakukan dengan menuliskan atau menceritakan temuan apa yang ada dalam langkah mencari informasi, mengasosiasi dan menemukan pola.

Kegiatan itu dikemukakan di depan siswa dengan melalui pengamatan yang cermat dan di evaluasi oleh guru dan siswa yang lain sebagai tindak lanjut dari proses belajar. Pada tahapan mengkomunikasikan hasil pembelajaran ini sebagaimana dikemukakan dalam Peraturan Menteri Pendidikan dan Kebudayaan (Permendikbud) Nomor; 81.a Th. 2013 adalah ; memberikan informasi hasil pengamatan dan menyimpulkan berdasar hasil analisa baik disampaikan secara lisan, tertulis, dan dapat menggunakan media lain". Hasil penelitian itu juga mendukung dari hasil penelitian sebelumnya, dimana dari beberapa hasil penelitian menyatakan bahwa pendekatan saintifik dapat berpengaruh terhadap nilai siswa agar supaya memperoleh nilai yang lebih baik lagi dari sebelumnya.

\section{KESIMPULAN}

Berdasar penelitian yang sudah dilakukan oleh peneliti, ditemukan adanya hasil penerapan pendekatan saintifik pada kelompok 5A masih tergolong kategori sedang, sedangkan penerapan pendekatan saintifik pada kelompok siswa 5B tergolong kategori tinggi, dengan pembuktian bahwa skor perolehan rata-rata yang diporoleh kelompok 5A adalah 12 yang tergolong kategori sedang, selanjutnya skor rata-rata yang diperoleh kelompok 5B yaitu 24 yang tergolong kategori tinggi.Penelitian ini juga menemukan adanya selisih hasil evaluasi yang mencolok di mana siswa yang pada proses belajar pendekatan saintifik tinggi dan siswa yang pada pendekatan saintifik rendah.

Evaluasi siswa yang ada pada proses belajar dengan penerapan pendekatan saintifik tinggi berada pada kategori tinggi, sedangkan evaluasi siswa yang pada proses belajar menggunakan penerapan pendekatan saintifik rendah berada pada kategori cukup. Dari temuan tersebut dapat diketahui bahwa perhitungan rata-rata evaluasi belajar Bahasa Indonesia menggunakan ukuran pendekatan saintifik tinggi adalah 24 lebih tinggi dari rata-rata perolehan evaluasi belajar bahasa Indonesia menggunakan pendekatan saintifik rendah yang hanya sebesar 12 .

\section{Saran}

Dari hasil penelitian telah peneliti lakukan, maka sebagai saran yang perlu disampaikan adalah : 
Pertama, guru disarankan supaya meningkatkan upaya mempelajari ragam pendekatan, salah satunya adalah ragam pendekatan saintifik yang nantinya akan digunakan dalam menyampaikan materi ke peserta didik guna meningkatkan hasil belajar, sebab pada tahapan tersebut siswa dituntut untuk aktif (student centered) dan tidak mutlak di dominasi oleh pendidik.

Kedua, bagi mahasiswa yang sedang belajar ilmu kependidikan atau calon guru dapat menambah serta menggali pemahaman yang lebih dalam lagi tentang pendekatan saintifik untuk selanjutnya dapat diterapkan nantinya apabila sudah menjadi guru atau memberikan masukan kepada para pendidik.

Ketiga, para peneliti yang sedang melakukan penelitian agar melakukan penelitian tindak lanjut tentang ragam Pendekatan Saintifik.

\section{UCAPAN TERIMAKASIH}

Terimakasih saya haturkan kepada semua pihak yang telah ikut berpartisipasi dan berperan dalam penerbitan jurnal ini, yang antara lain :

1. Kedua orang tuaku sebagai superheroku.

2. Istri dan anak-anaku sebagai motivasi terbesarku.

3. Bapak Dr. Abdul Wachid B.S. S.S., M.Hum. sebagai dosen pembimbingku.

4. Kepala MI Muhammadiyah Langgar beserta dewan gurunya.

5. Rekan-rekanku seperjuangan di pasca sarjana yang tidak bosan membantuku.

\section{DAFTAR PUSTAKA}

Agung, A. A. Gede. 2014. Buku Ajar Metodologi Penelitian Pendidikan. Malang: Aditya Media Publising.

Arifin, Zainal. 2012.Evaluasi Pembelajaran, Bandung: Remaja Rosdakarya

Daryanto, 2014.Pendekatan Pembelajaran Saintifik. Yogyakarta: Gava Media

Dantes, Nyoman. 2012. Metodelogi Penelitian. Yogyakarta: C.V Andi Offset.

Diadnya, I W. 2012.Pengaruh Penerapan Model Pembelajaran Inkuiri terhadap Hasil Belajar IPA Ditinjau dari Kemampuan Berpikir Divergen Siswa Kelas VII SMP Negeri 4 Mendoyo Semester I Tahun Pelajaran 2011/2012.Tesis.Singaraja : Program Pasca Sarjana Undiksa.

Gading, I Kt. 2014.Pengaruh Pelatihan Kendali diri dan Jenis Kelamin terhadap Prilaku Prokrastinasi Akademik Siswa SMP.Disertansi.Malang : Sarjana Universitas Negeri Malang.

Guilford, J.P., Fruchter, B. 1973. FundamentalStatistics in Psychology and Education, Fifth Edition.Tokyo : McGraw-Hill Kogakusha, Ltd.

Hidayat, Syah. 2014. Pengantar Umum Metodelogi Penelitian Pendidikan Pendekatan Verisikatif. Pekan

Baru : Suskafres

Koyan, I Wayan.2012.Statistik Pendidikan Teknik Analisis data Kuantitatif.Singaraja : Universitas Pendidikan Ganesha Press.

Kurniasih, Imas, Dan Sani, Berlin. (2014). Implementasi Kurikulum 2013 : Konsep dan Penerapan. Surabaya: Kata Pena.

Kurinasih, Imas dan berlin Sani. 2014. Sukses Mengimplementasikan Kurikulum 2013. Jakarta : Kata Pena.

Marjan, Johari. 2014. Pengaruh Pembelajaran Pendekatan Saintifik terhadap Hasil Belajar Biologi dan Keterampilan Proses Sains Siswa Ma.

Mu'llimat Nahdlatul Wathan Pancor Tahun Pelajaran 2013/2014.Tesis.Singaraja : Pasca Sarjana Undiksha. 
Mudalara, Putu. 2012. Pengaruh Model Pembelajaran Inkuiri Bebas terhadap hasil Belajar Kimia Siswa Kelas XI IPA SMA Negeri 1 Gianyar Ditinjau dari Sikap Ilmiah. Tesis.Singaraja : Program Pasca arjana Undiksa.

[Permendikbud] Peraturan Menteri Pendidikan dan Kebudayaan Nomor 81 A. 2013. Implementasi Kurikulum 2013. Jakarta: Kementerian Pendidikan dan Kebudayaan.

Suarsani, G. A. 2011. Pengaruh Model Pembelajaran Inkuiri Terbimbing terhadap Hasil Belajar Kimia Siswa Kelas XI IPA SMA PGRI Gianyar 3 Ubud.Tesis.Singaraja : Program Pasca Sarjana. Undiksa.

Sarini, Putri. 2012. Pengaruh Virtual Experiment terhadap Hasil Belajar Fisika Ditinjau dari Motivasi.

\section{BIOGRAFI PENULIS}

$\begin{aligned} & \text { Penulis 1 } \\ & \text { Nama : Muslihun } \\ & \text { TTL : Banjarnegara, 13 April 1970 } \\ & \text { Pekerjaan : Mahasiswa Pasca Sarjana UIN Prof. KH. Saifudin Zuhri Purwokerto } \\ & \text { Alamat : Dusun Karang Anyar, Desa Langgar, Kejobong, Purbalingga 53392 }\end{aligned} \mid \begin{aligned} & \text { Abdul Wachid B.S., lahir 7 Oktober 1966 di Bluluk, Lamongan, Jawa Timur. } \\ & \text { Wachid lulus Magister Humaniora Sastra Indonesia UGM, jadi dosen-negeri di } \\ & \text { IAIN Purwokerto, dan lulus Doktor Pendidikan Bahasa Indonesia di Universitas } \\ & \text { Negeri Sebelas Maret Solo (15/1/2019). }\end{aligned}$

